\title{
Estimates of genetic parameters using six populations in two bread wheat crosses
}

\author{
Ahmed B. H.* \\ Agronomy Department, Faculty of Agriculture, Al-Azhar University, Assiut, Egypt
}

\begin{abstract}
Six populations of two wheat hybrids, namely Sids $14 \times$ Giza 171 and Sids $14 \times$ Gemmeiza 11 were established during three successive seasons of 2017/2018, 2018/2019 and 2019/2020. The results showed that there are significant differences between the mean of six populations in the cross- crossing of wheat crosses for most the studied traits, it is possible to obtain sufficient amounts of genetic variation for these traits in the studied material. The additive gene effects were significant for all traits studied except for $\mathrm{DH}$ in cross 1 and NSP in cross 2 . The highest significant effects of the dominant genes were found to be highly significant for most traits under study, except for the number of grains/spike in the hybrid 2 . The additive $\times$ additive type of gene effects was positive and highly significant for plant height and weight of 100 grains in the two crosses, and 50\% flowering to heading and grains yield/plant in cross 1 . High expected genetic advance was recorded in the second generation $\left(\mathrm{F}_{2}\right)$ for grain yield per plant in the two hybrids, The results showed that there is an improvement in the genotypes possible through early selection of the higher crop.
\end{abstract}

Keywords: wheat, six population analysis, genes, heterosis, heritability, genetic advance. 


\section{Introduction}

Wheat (Triticum aestivum L.) is first food crops in Egypt. About 730.3 million tons of wheat were produced from 217 million hectares in 2010 and 2017/2018 at a productivity level of 3 tons $/ \mathrm{ha}^{-1}$ (Brown et al., 2010; FAO, 2012; 2019). It is a food staple for millions of people because it provides $50 \%$ of the calorie and protein requirements of a large number of the world's population. The grain yield can be improved through indirect selection on the basis of yield components. The breeder is focusing on improving wheat yield potential by developing now divergent genotypes with a trait that may have a positive and negative effect on traits of other components (Chandara et al., 2004). Besides, factors controlling the reported heritability estimates largely indicate that some morphological traits affecting grain yield in wheat are more heritable than the crop itself (Fatehi and Mohamed, 2010). Generation mean analysis techniques were used to obtain significant information about the types of action of genes controlling yield and yield components as well as traits. The main objective of this research is to study the relative importance of genetic action, genetic progression, inbreeding depression and the degree of control of sexual traits in two bread wheat crosses using their six groups, i.e., $\mathrm{P}_{1}, \mathrm{P}_{2}$, $\mathrm{F}_{1}, \mathrm{BC}_{1}, \mathrm{BC}_{2}$ and $\mathrm{F}_{2}$.

\section{Materials and methods}

The search has been performed in 2017/2018, 2018/2019, and 2019/2020 growing seasons, at the Experimental Farm of Faculty of Agriculture, Al-Azhar University, Assiut, Egypt. Three bread wheat cultivars were used. The name, pedigree origin and of these broad wheat genotypes are presented in Table (1). In 2017/2018 season the parents were crossed produce F1 hybrid grains and designated as follows: In 2018/2019 season some, $F_{1}$ plants were back crossed to their parents to produce $\mathrm{BC}_{1}\left(\mathrm{~F}_{1} \times \mathrm{P}_{1}\right)$ and $\mathrm{BC}_{2}\left(\mathrm{~F}_{1} \times \mathrm{P}_{2}\right)$ generations. Also, crosses were made to produce more $F_{1}$ grains. At the same time, some $F_{1}$ hybrids were selfed to produce $F_{2}$ generation. In 2019/2020 season the six populations, i.e., $\mathrm{P}_{1}, \mathrm{P}_{2}, \mathrm{~F}_{1}, \mathrm{~F}_{2}, \mathrm{Bc}_{1}$ and $\mathrm{Bc}_{2}$ of the two hybrids were sown in a randomized complete blocks design with three replicates. Each replicate consisted of 44 rows ( 16 rows for $\mathrm{F}_{2}, 8$ rows for each $\mathrm{BC}_{1}$ and $\mathrm{BC}_{2} 4$ rows each for $\mathrm{P}_{1}, \mathrm{P}_{2}$ and $\mathrm{F}_{1}$ ). Each row was $5.0 \mathrm{~m}$ long, $60 \mathrm{~cm}$ apart and $20 \mathrm{~cm}$ between plants. The agriculture practices recommended for wheat production were adopted in all the growing seasons. Characters were assesses using individual plants from the six populations ( 30 plants for each $\mathrm{P}_{1}, \mathrm{P}_{2}$, and $\mathrm{F}_{1}, 60$ plants for each $\mathrm{BC}_{1}$ and $\mathrm{BC}_{2}$ and 120 plants for each $\mathrm{F}_{2}$ population) the following characters were studied characters, i.e., days to $50 \%$ heading $(\mathrm{DH})$, plant height $(\mathrm{PH})(\mathrm{cm})$, number of spike/plant (NSP), number of kernels/spike (NKS), 1 weight of 100 grains (GW) (g) and (GYP) grain yield/plant $(\mathrm{g})$. 
Table (1): The name, pedigree and origin of genotypes used in the two bread wheat crosses.

\begin{tabular}{|c|c|l|c|c|}
\hline \multicolumn{2}{|c|}{ Cross } & Parent & Pedigree & Origin \\
\hline \multirow{2}{*}{ Cross 1 } & P1 & Sids- 14 & $\begin{array}{c}\text { BOW"S"/Vee"S"//Bow"S"/TSI/3/Beni Sewef 1 } \\
\text { SD293-1SD-2SD-4SD -Osd }\end{array}$ & Egypt \\
\cline { 2 - 5 } & P2 & Giza-171 & Sakha93/ Gemmeiza 9 & Egypt \\
\hline \multirow{3}{*}{ Cross 2 } & P1 & Sids- 14 & $\begin{array}{c}\text { BOW"S"/Vee"S"//Bow"S"/TSI/3/Beni Sewef 1 } \\
\text { SD293-1SD-2SD-4SD -Osd }\end{array}$ & Egypt \\
\cline { 2 - 5 } & P2 & Gemmeiza 1 1 & $\begin{array}{c}\text { BOW"S"/KVZ"S"//7C/SERI-82/3/GIZA 168/SAKHA 61 } \\
\text { GM7892-2GM-1GM-2GM-1GM-0GM }\end{array}$ & Egypt \\
\hline
\end{tabular}

\subsection{Statistical and genetic analysis}

All the genetic analysis were done using generation means, the scaling tests (A, B and C) were applied according to Mather and Jinks (1982) to test the presence of non-allelic interaction as following:

$$
\begin{aligned}
& \mathrm{A}=2 \overline{\mathrm{B}_{1}}-\overline{\mathrm{P}_{1}}-\overline{\mathrm{F}_{1}} \\
& \mathrm{~B}=2 \overline{\mathrm{B}_{2}}-\overline{\mathrm{P}_{2}}-\overline{\mathrm{F}_{1}} \\
& \mathrm{C}=4 \overline{\mathrm{F}_{2}}-2 \overline{\mathrm{F}}_{1}-\overline{\mathrm{P}_{1}}-\overline{\mathrm{P}_{2}}
\end{aligned}
$$

Those parameters genetic model ( $\mathrm{m}, \mathrm{a}, \mathrm{h}$, aa, ad and dd) were according to Jinks and Jones (1958) and Hayman (1958):

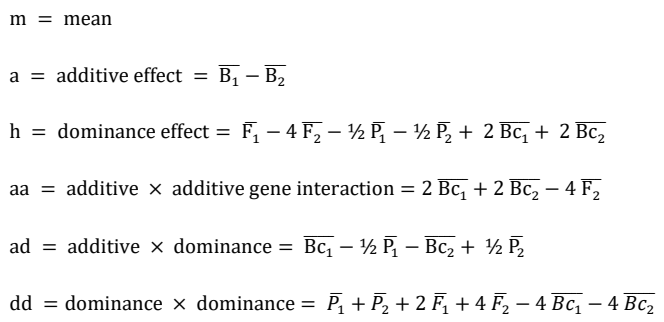

The genetic components of variance were calculated by the formulas of $\mathrm{F} 2$ variance were obtained according to Mather and Jinks (1982) as:

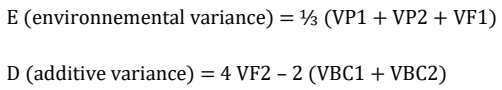

$\mathrm{H}($ dominance variance $)=4(\mathrm{VF} 2-1 / 2 \mathrm{VD}-\mathrm{VE})$

The significant of the genetic components were tested using the $\mathrm{t}$ test, where $\mathrm{t}=$ effect / (variance effect) ${ }^{1 / 2}$.

\subsection{Heterosis}

Estimate of heterosis (\%) were calculated as the percent deviation of $F_{1}$ mean performance from the mid-parent or better parent as follows:

Heterosis from the mid - parent $\left.\%(\mathrm{M} . \mathrm{P})=\left(\overline{\mathrm{F}_{1}}-\overline{\mathrm{MP}}\right) / \overline{\mathrm{MP}}\right) \times 100$

Heterosis from the better - parent $\left.\%(\mathrm{BP})=\left(\overline{F_{1}}-\overline{\mathrm{BP}}\right) / \overline{\mathrm{BP}}\right) \times 100$

\subsection{Inbreeding Depression (I. D \%)}

Its values measured from the following equation:

$$
\begin{aligned}
& \text { I. } \%=\left(\overline{\mathrm{F}_{1}}-\overline{\mathrm{F}_{2}} / \overline{\mathrm{F}_{1}}\right) \times 100 \\
& \text { Variances of I. D deviation }=\overline{\mathrm{VF}_{1}}+\overline{\mathrm{VF}_{2}} \\
& \text { T: I. } \mathrm{D}=\overline{\mathrm{F}_{1}}+\overline{\mathrm{F}_{2}} /(\text { V.I. D })^{0.5}
\end{aligned}
$$

Phenotypic and genotypic coefficients of variability were calculated as outlined by Burton (1952):

$$
\begin{aligned}
& \mathrm{PCV}=(\sqrt{\mathrm{VP}} / \overline{\mathrm{X}}) \times 100 \\
& \mathrm{GCV}=(\sqrt{\mathrm{VG}} / \overline{\mathrm{X}}) \times 100
\end{aligned}
$$




\subsection{The average degree of dominance $(\bar{a})$}

The average degree of dominance $(\overline{\mathrm{a}})$ : was calculated by the formula presented by Mather and Jinks (1982):

$\overline{\mathrm{a}}=(\mathrm{H} / \mathrm{D})^{1 / 2}$

Complete dominance is considered when $\overline{\mathrm{a}}= \pm 1.0$, partial dominance is indicated when a lise between \pm 1.0 , while overdominance is considered if lies the ratio exceeded \pm 1.0 . if degree of dominance value is equal to zero, it indicates the absence of dominance. The positive and negative signs indicate the direction of dominance.

\subsection{Heritability}

\subsubsection{Heritability in broad-sense $\left(h^{2}{ }_{b}\right)$}

Heritability in broad-sense $\left(\mathrm{h}^{2} \mathrm{~b}\right)$ was estimated according to the following formula presented by Mather and Jinks (1982):

$\mathrm{h}^{2} \mathrm{~b} \%=(\mathrm{VG} / \mathrm{VP}) \times 100$

\subsubsection{Heritability in narrow-sense $\left(h^{2}{ }_{n}\right)$}

It was estimated according to the following formula presented by Mather and Jinks (1982):

$\mathrm{h}^{2} \mathrm{n} \%=(1 / 2 \mathrm{D} / \mathrm{VP}) \times 100$

\subsection{Expected gain from selection (G.S)}

The expected gain from selecting (G.S) was calculated according to Allard (1960):

G.S $\%=\left[\left(\mathrm{K} \times \sigma \mathrm{ph} \times \mathrm{h}^{2} \mathrm{n}\right) / \mathrm{F}_{2}\right] \times 100$

\section{Results and Discussion}

The mean values and standard error for the sixth generation were calculated with the two hybrids for six traits and presented in Table (2). The results showed that there are significant differences between the mean of six populations in the crosscrossing of wheat crosses for all studied characters, which indicates the presence of a sufficient amount of genetic variation for these traits in the studied material. Results showed that the mean values of $\mathrm{F}_{1}$ were higher than for all parents, $\mathrm{BC}_{1}$ and $\mathrm{BC}_{2}$ for $50 \%$ flowering of heading, NSP, NKS and GYP in the two hybrids, excluding $\mathrm{PH}$ and weigh of 100 grains in both hybrids. The backcrossed mean values were larger than both parents in the two crosses for days to $50 \%$ heading and GYP. The backcrossed mean values were higher than both parents in the two hybrids for NSP and weigh of 100 grains in second cross. The mean values of the first and second back - generations were higher than in $\mathrm{P}_{2}$ for number of grains per spike for both hybrids. Regarding the mean value for the second generation were lower than the median values $\mathrm{F}_{1} 50 \%$ flowering of heading, NSP, NKS and GYP in two hybrids, except, $\mathrm{PH}$ and weigh of 100 grains in the two hybrids, Genetic variance is high in all traits, with $\mathrm{PH}$ and 100-grain weight excluded in two 
hybrids, while the F-value was lower than in both parents. Similar results were obtained with Awad (1996), Amin (2013), Al-Masry and Al-Nahhas (2018).

Table (2): Mean performance of parents, $F_{1}, F_{2}$, and back crosses generations in two bread wheat crosses for all studied traits.

\begin{tabular}{|c|c|c|c|c|c|c|}
\hline Characters generation & Days to 50 heading & Plant height & No. spike/plant & No. kernels/spike & Weight 100 - grains & Grain yield \\
\hline \multicolumn{7}{|c|}{ Cross $1($ Sids $14 \times$ Goemiza 11$)$} \\
\hline $\mathrm{P}_{2}$ & $97.53 \pm 0.408$ & $110.83 \pm 0.561$ & $6.33 \pm 0.021$ & $58.20 \pm 0.965$ & $5.00 \pm 0.011$ & $16.60 \pm 0.609$ \\
\hline $\mathrm{F}_{2}$ & $99.85 \pm 0.660$ & $93.17 \pm 0.586$ & $7.26 \pm 0.80$ & $73.15 \pm 1.27$ & $4.16 \pm 0.07$ & $18.71 \pm 0.603$ \\
\hline $\mathrm{BC}_{1}$ & $106.44 \pm 0.738$ & $104.95 \pm 0.757$ & $6.84 \pm 0.034$ & $66.07 \pm 1.81$ & $5.15 \pm 0.009$ & $19.23 \pm 0.647$ \\
\hline $\mathrm{BC}_{2}$ & $98.68 \pm 0.679$ & $100.16 \pm 0.851$ & $6.33 \pm 0.029$ & $71.55 \pm 1.72$ & $4.54 \pm 0.005$ & $22.36 \pm 0.802$ \\
\hline L. S.D.0.05 & 1.70 & 1.60 & 0.860 & 2.36 & 0.555 & 1.62 \\
\hline $\mathrm{P}_{2}$ & $93.79 \pm 0.469$ & $111.51 \pm 0.874$ & $6.57 \pm 0.436$ & $73.31 \pm 1.33$ & $4.78 \pm 0.10$ & $24.33 \pm 0.559$ \\
\hline$F_{1}$ & $99.76 \pm 0.769$ & $108.49 \pm 0.954$ & $10.07 \pm 0.445$ & $76.96 \pm 2.00$ & $4.70 \pm 0.180$ & $29.66 \pm 1.128$ \\
\hline $\mathrm{F}_{2}$ & $96,73 \pm 0.669$ & $109.19 \pm 0.678$ & $7.26 \pm 0.168$ & $74.83 \pm 1.11$ & $4,86 \pm 0.062$ & $25.45 \pm 0.632$ \\
\hline $\mathrm{BC}_{1}$ & $97.76 \pm 0.890$ & $108.75 \pm 0.907$ & $9.21 \pm 0.345$ & $76.55 \pm 1.50$ & $5.49 \pm 0.082$ & $25.91 \pm 0.653$ \\
\hline $\mathrm{BC}_{2}$ & $96.11 \pm 0.764$ & $116.35 \pm 0.720$ & $9.98 \pm 0.322$ & $66.11 \pm 1.46$ & $5.20 \pm 0.086$ & $26.29 \pm 0.820$ \\
\hline L. S.D. 0.05 & 1.71 & 1.72 & 1.05 & 2.21 & 0.522 & 1.66 \\
\hline
\end{tabular}

Results of scaling test (A, B and C) together with the six parameters model and type of epistasis are calculated and given in Table (3). It is worthy to mention that the least one of the $\mathrm{A}, \mathrm{B}$ and $\mathrm{C}$ tests were significant for all studied traits except, $50 \%$ flowering to heading in cross 1. It can be said from the obtained results that the six parameters model is valid to explain the nature of the gene. Furthermore, the $\mathrm{A}, \mathrm{B}$, or $\mathrm{C}$ measures were not significant, indicating that the interactive model failed to explain the type of gene action in this case. These results are in general agreement with those of Shafey et al. (1993), Tammam (2005), Kattab et al. (2010), El-Aref et al. (2011), Zaazaa et al. (2012), and Amin (2013) for NSP and NKS and GYP and Moussa (2010) for DH, PH, and 100-grain weight by Lal et al. (2013). On the other hand, Abdel-Radi (2018) explained that the scaling test indicated a non-allelic interaction for all studied traits except for NSP in hybrid 2 and NGS and GYP in hybrid 1 under normal conditions.

Table (3): The scaling test and estimates of the additive (D), dominance $(\mathrm{H})$ and interaction parameters in two bread wheat hybrids for all studied traits.

\begin{tabular}{|c|c|c|c|c|c|c|c|c|c|c|}
\hline \multirow{2}{*}{ Character } & \multirow{2}{*}{ Cross } & \multicolumn{9}{|c|}{ Genetic parameter } \\
\hline & & A & B & $\mathrm{C}$ & $\mathrm{M}$ & A & $\mathrm{H}$ & $\mathrm{Aa}$ & $\mathrm{Ad}$ & $\mathrm{dd}$ \\
\hline \multirow{2}{*}{ Days to $50 \%$ heading } & 1 & $12.03^{* * *} \pm 1.61$ & $6.36^{* * *} \pm 1.48$ & $-5.5 \pm 2.86$ & $99.85^{* * *} \pm 0.66$ & $7.78^{* *} \pm 1.00$ & $21.38 * * \pm 3.07$ & $10.9 * * \pm 3.33$ & $9.33 * * \pm 1.05$ & $-16.30^{* * *} \pm 4.94$ \\
\hline & 2 & $1.43 \pm 2.00$ & $-1.33 \pm 1.77$ & $3.28 \pm 3.16$ & $96.73 * 8 \pm 0.669$ & $1.65 \pm 1.17$ & $6.52 * \pm 3.65$ & $0.82 \pm 3.56$ & $1.38 \pm 1.22$ & $-.92 \pm 5.65$ \\
\hline Plant height & 1 & $7.46^{* *} \pm 1.78$ & $-1.63 \pm 1.95$ & $-31.7 * * \pm 2.97$ & $93.17^{* * *} \pm 0.586$ & $4.78^{* * \pm 1.13}$ & $17.60^{* *} \pm 3.12$ & $37.53^{* * *} \pm 3.26$ & $4.54 * * \pm 1.20$ & $-43.36^{* * *} \pm 5.41$ \\
\hline \multirow[b]{2}{*}{ Number of spikes/plant } & 1 & $-0.730 \pm 0.461$ & $-1.03^{* *} \pm 0.418$ & $0.96 \pm 0.92$ & $7.26 * * \pm 0.168$ & $0.50 * \pm 0.27$ & $-2.52^{* *} \pm 0.889$ & $-2.73 * * \pm 0.860$ & $0.15 \pm 0.31$ & $3.56^{*} \pm 1.45$ \\
\hline & 2 & $1.32 \pm 0.862$ & $3.32 * * \pm 0.89$ & $-2.18 \pm 1.43$ & $7.46 * * \pm 0.251$ & $-0.77 \pm 0.477$ & $11.81 * * \pm 1.47$ & $8.54 * * \pm 1.39$ & $-1.00 \pm 0.536$ & $13.18^{* *} \pm 2.37$ \\
\hline \multirow{2}{*}{ Number of kernels/spike } & 1 & $6.18 * * \pm 3.07$ & $20.97 * * \pm 2.99$ & $44.53^{* * *} \pm 5.68$ & $73.15^{* * * \pm 1.27}$ & $-5.47 * * \pm 1.88$ & $-13.58^{*} \pm 5.95$ & $-17.37 * * \pm 6.32$ & $-7.39 * * \pm 2.01$ & $-9.78 \pm 9.42$ \\
\hline & 2 & $14.1^{* *} \pm 3.75$ & $-18.05^{* *} \pm 3.79$ & $-10.87 \pm 6.22$ & $74.83^{* * *} \pm 1.11$ & $10.44 * \pm 2.100$ & $-4.71 \pm 6.49$ & $-14.00^{* *} \pm 6.12$ & $16.07 * * \pm 2.26$ & $17.95 * * \pm 2.26$ \\
\hline \multirow{2}{*}{ Grain yield/plant } & 1 & $-5.65^{* *} \pm 1.70$ & $2.45 \pm 1.97$ & $-11.53^{*} \pm 3.29$ & $18.71^{* *} \pm 0.603$ & $-3.12 * * \pm 1.03$ & $16.47 * * \pm 3.23$ & $8.34 * * \pm 3.17$ & $-4.05 * * \pm 1.110$ & $-5.15 \pm 5.22$ \\
\hline & 2 & $3.71^{* * \pm 1.81}$ & $-1.41 \pm 2.06$ & $7.17 * * \pm 3.84$ & $25.45^{* *} \pm 0.632$ & $-0.371 * * \pm 1.04$ & $10.88 * * \pm 3.49$ & $2.61 \pm 3.28$ & $-4.34 * * \pm 0.559$ & $-4.92 \pm 5.45$ \\
\hline
\end{tabular}




\subsection{Gene effects}

The six parameters of gene effect, i.e., means $(\mathrm{m})$, additive $(\mathrm{d})$, dominance $(\mathrm{h})$, additive $x$ additive (aa), additive $\times$ dominance $(\mathrm{ad})$ and third type of epistatic effect dominance $\times$ dominance $(\mathrm{dd})$ are presented in Table (3). Average is high and significant in all traits in the two hybrids. The additive gene effects (d) all traits studied were significant $(*)$ and either positive or negative except for $50 \%$ flowering to heading in hybrid 1 and number of spikes/plant in hybrid 2. These result agreement with those obtained by Khattab et al. (2010), Abd El-Rahman (2013), Amin (2013) and Elmassrya and El- Nahas (2018). Also, Zaazaa et al. (2012) found that the additive gene effects were not significant except NGS and GYP in hybrid III and NGS in hybrid I. The value dominance gene effects $(\mathrm{h})$ were found to be significant (*) and highly significant $(* *)$ for most studied traits except for NKS in hybrid 2. While it was negative and highly significant for NSP and NKS in cross1. The additive gene effects (d) less than dominance effects (h). These results are in harmony with those obtained by Khattab et al. (2010) and Zaazaa et al. (2012) for PH, NSP, NKS, 100 grains weight and GYP. Dominance effects were generally greater than additive, except for NKS in cross 2 . These results are in accordance with those by Khaled (2013). The values additive $\times$ additive (aa) type of gene effects was positive and highly significant for $\mathrm{PH}$ and 100 -grain weight in two hybrids, and DH and GYP in cross 1. While it was negative and highly significant were by obtained by NKS in two crosses and not significant for days to DH and GYP in hybrid 2. So, early generations selection for these characters might be effective for weight breeding program where it was found that the inter action between the additional alleles is of very importance, especially in autologous crops such as wheat, unlike the hybrid crops in which the interaction between the dominant alleles is of great importance because it depends on the strength of the hybrid. This is a very crop. These accordance with those by Amin (2013). On the other hand, Akhtar and Chowedry (2006) revealed that the negative $(d \times d)$ type of gene effects, were recorder for PH and GYP. The parameters additive $\mathrm{x}$ dominance (ad) was Significant and positive highly significant for $\mathrm{DH}, \mathrm{PH}$ in hybrid 1and NKS in cross 2 and 100grain weight in two crosses, while it was negative and highly significant were by obtained by GYP in two crosses and PH and NKS in cross 2 . The additive $\times$ dominance gene effects was not significant for DH in cross 2 and NSP in two crosses. Similar results have been reported by Abd El- Rahman and Hammad (2009) for number of kerlines per spike and kernel weight. The dominance $\times$ dominance $(\mathrm{dd})$ gene interactions was significant $(*)$ or significant (**) and positive in cross 1 . for NSP and number of NKS in two crosses. Similarly, Fethi and Mohamed (2010) found that the parameters dominance effects and third types of epistatic 
dominance $\times$ dominance $(\mathrm{dd})$ epistasis were more important than additive effects and other epistasis components for NKS. A significant or highly significant and negative $\mathrm{d} \times \mathrm{d}(\mathrm{dd})$ gene interactions were obtained in two for plant height and 100grain weight and days to $50 \%$ heading in hybrid 1 . Also, found that the dominance $x$ dominance $(\mathrm{dd})$ gene effects were not significant for DH and NKS in hybrid 1 and GYP in the two hybrids. These results agree with those reported by El-Aref et al. (2011) and Amin (2013). The type of epistasis was determined as complementary when dominance (d) and third type of epistatic effect (dd) gene effects have same sign and duplicate epistasis when the sign was different. Thus, selection in the early generations is effective when the additive effects is greater than the non-additive effect, also, the non-additive portion are greater than additive, the improvement of the characters needs intensive selection through later generations. These results are in harmony with those reported by Kattab et al. (2010), Amin (2013) and Abd El- Rady (2018).

3.2 Heterosis, inbreeding depression (\%) and phenotypic $(P C V)$ and genotypic $(G C V)$ coefficient of variation

Heterosis, inbreeding depression (\%) and phenotypic (PCV) and genotypic (GCV) coefficient of variation in two bread wheat hybrids for all traits studied are presented in Table (4). Heterosis estimates relative to MP and BP were found to be highly significantly positive for days to $50 \%$ heading, NSP and GYP in both crosses and NKS in cross 1. Heterosis above mid parent recorded for number of kernels per spike in cross 1 . While it was negative it was significantly negative for 100 kernels weight in both crosses and plant height in cross 1 . While it was non significantly for plant height in cross 2 . These results are in harmony with obtained by Kattab et al. (2010), Zaazaa et al. (2012), Abd Alla and Hassan (2012) and Elmassry and ElNahas (2018). Kumar et al. (2018) reported that significant and positive mid parent (M.P) and better parent (B.P) heterosis were observed in four hybrids for grain yield per plant. Concerning inbreeding depression value, positive and highly significant most traits in two hybrids, however, it was highly significant and negative for plant height in the two hybrids. However, these results the expected as the expression of heterosis in $F_{1}$ will be followed by considerable reduction in $F_{2}$ due to homozygosis. The results are in similar with Zaazaa et al. (2012) and El massry and El-Nahas (2018) for NSP, NKS and GYP and Moussa (2010) for days to heading Kumar et al. (2018) found that significant inbreeding depression (I.D) was recorded frequently for yield and yield contributing traits. The phenotypic coefficient (PCV) of variability values were higher than (GCV) for all traits studied in the two crosses (Table 4). Results indicated that the PCV and GCV values were much close, these revealed the major proportion of the observed variation was contributed by the genetic 
factor in additive genetic variance in most values for phenotypic coefficient and genotypic coefficient of variability. Therefore, these traits were highly affected by environmental factors. The results agreed with those obtained by Zaazaa et al. (2012).

\subsection{Genetic variance and of three parameters model}

The assessment of genetic variance, additive (D)and dominance $(\mathrm{H})$ gene effects in Table (5). The results revealed that the (a) genetic variance was less than (d) for all traits in two hybrids, while the (a) genetic variance was higher than (d) for DH and GYP $(\mathrm{g})$ in hybrid 1, indicated that the additive gene effects play the main role in the inheritance of these traits and using selection in early segregating generations could be effective to isolate lines characterized by high grain yield under this study. Similar results were reported by El-Aref et al. (2011), Amine (2013) and Abd El- Rady (2018).

Table (4): Heterosis, inbreeding depression \%, phenotypic (PCV) and genotypic (GCV) coefficient of variation in two bread wheat hybrids for all characters studied traits.

\begin{tabular}{|c|c|c|c|c|c|c|}
\hline \multirow{2}{*}{ Characters } & \multirow{2}{*}{ Crosses } & \multicolumn{2}{|c|}{ Heterosis \% } & \multirow{2}{*}{ Inbreeding depression \% } & \multirow{2}{*}{ P.C.V \% } & \multirow{2}{*}{ G.C.V. $\%$} \\
\hline & & MP & BP & & & \\
\hline \multirow{2}{*}{ Days to $50 \%$ heading } & 1 & $10.92 * *$ & $9.15 * *$ & $6.21 * *$ & 7.31 & 6.90 \\
\hline & 2 & $6.05 * *$ & $5.75^{* * *}$ & $3.03 * *$ & 7.57 & 6.80 \\
\hline \multirow{2}{*}{ Plant height } & 1 & $-17.94 * *$ & $-17.77 * *$ & $-2.24 * *$ & 6.89 & 5.62 \\
\hline & 2 & -2.61 & -2.70 & $-0.64 * *$ & 6.80 & 5.46 \\
\hline \multirow{2}{*}{ Number of spikes/plant } & 1 & $3.24 * *$ & 8.94 ** & $1.40 * *$ & 30.49 & 27.35 \\
\hline & 2 & $48.08 * *$ & $43.24 * *$ & $25,91 * *$ & 36.88 & 23.23 \\
\hline \multirow{2}{*}{ Number of kernels/spike } & 1 & $6.30^{* * *}$ & $9.80^{* * *}$ & $6.33 * *$ & 16.83 & 14.19 \\
\hline & 2 & $13.71^{\text {*** }}$ & 4.97 & $2.76^{* * *}$ & 16.30 & 11.95 \\
\hline \multirow[t]{2}{*}{ Wighet of 100 - grains } & 1 & $-6.36 * *$ & -8.32 *** & $9.25 * *$ & 18.92 & 12.87 \\
\hline & 2 & $-1.87 * *$ & $-2.08 * *$ & $9.15 * *$ & 13.98 & 8.19 \\
\hline \multirow{2}{*}{ Grain yield/plant } & 1 & $46.38^{* * *}$ & $54.54 * *$ & $27.07 * *$ & 35.34 & 26.52 \\
\hline & 2 & $38.63^{* * *}$ & 21.08 ** & $14.19 * *$ & 27.23 & 21.20 \\
\hline
\end{tabular}

$*$ and ** Significant and high Significant at 0.05 and 0.01 level of probabilities.

The average degree of dominance $(\mathrm{H} / \mathrm{D})^{0.5}$ given in Table (5) revealed that partial dominance gene effects was presented for all traits in hybrid 1 and weight of 100 grains in cross 2 . While it was, revealed that over dominance towards the BP for all traits in hybrid 2 and plant height in hybrid 1 except, number of kerlines per spike in cross 2. Khattab et al. (2010), Amin (2013) and El-Gammaal and Yahya (2018) found the same results. On the other hand, Abd-Allah and Mostafa (2011) found that the complete dominance was found for NSP and 100-kernel weight in the first cross whereas, over dominance $(p>1)$ was detected for grain yield and its attributes in the $2^{\text {nd }}$ cross.

\subsection{Heritability in broad $(\mathrm{Hb})$ and narrow} $(\mathrm{Hn})$ senses and genetic advance

Heritability estimates indicate that the progress from selection for plant characters is relatively easy or difficult to make in breeding program. Heritability estimates in broad and narrow-sense and genetic advance (G.S \%) are presented in Table (5). Heritability values in broad 
sense were moderate to high for all studied traits in the two hybrids ranging from $34.34 \%$ for 100 kernels weight in cross1 to 89.04 for plant height in cross 1. Narrow sense heritability values were moderate to high in most traits except $\mathrm{PH}$ in cross 1, NSP in two crosses, NKS in cross 2 and 100 kernels weight in cross 1 , indicating that these traits were greatly affected by additive and non-additive effects and there is appreciable amount of heritable variation. Meanwhile, the remaining traits which had low narrow sense heritability estimates, show that selection for these traits will be difficult and high environmental influence well be a problem. These results are in accordance with the findings of $\mathrm{El}$-Aref et al. (2011), Amin (2013), Abd El -Rady (2018), El Massry and El-Nahas (2018), and El-Gammaal and Yahya (2018). ElSaid, Rania (2018) reported that the heritability in broad-sense were high values detected for all the studied traits, indicated that these traits are more genetic, while narrow sense heritability were low for NSP and GYP, so the role of additive part is low.

Table (5): Genetic variance, broad $\left(\mathrm{H}_{\mathrm{b}}\right)$ and narrow $\left(\mathrm{h}_{\mathrm{n}}\right)$ sense heritability and expected genetic advance (G.S\%) for traits in two crosses.

\begin{tabular}{|c|c|c|c|c|c|c|c|c|c|}
\hline \multirow{2}{*}{ Characters } & \multirow{2}{*}{ Crosses } & \multicolumn{3}{|c|}{ Genetic variance } & \multirow{2}{*}{$(\mathrm{H} / \mathrm{D})^{1 / 2}$} & \multicolumn{2}{|c|}{ Heritability } & \multicolumn{2}{|c|}{ G.S \% } \\
\hline & & $\mathrm{D}$ & $\mathrm{H}$ & $\mathrm{E}$ & & $\mathrm{Hb}$ & $\mathrm{Hn}$ & $\mathrm{Hb}$ & $\mathrm{Hn}$ \\
\hline \multirow{2}{*}{ Days to heading } & 1 & 92.47 & 5.23 & 5.84 & 0.237 & 89.04 & 86.60 & 7.55 & 6.89 \\
\hline & 2 & 49.78 & 179.66 & 10.49 & 1.89 & 80.48 & 46.29 & 8.84 & 5.08 \\
\hline \multirow{2}{*}{ Plant height } & 1 & 9.11 & 91.77 & 13.71 & 3.17 & 72.22 & 11.07 & 15.41 & 2.36 \\
\hline & 2 & 59.88 & 171.30 & 19.63 & 1.69 & 64.43 & 54.21 & 6.35 & 5.35 \\
\hline \multirow{2}{*}{ Number of pikes/plant } & 1 & 2.01 & 11.59 & 0.96 & 0.425 & 80.45 & 21.14 & 35.57 & 9.46 \\
\hline & 2 & 3.48 & 23.97 & 4.56 & 2.62 & 39.67 & 22.98 & 21.12 & 12.29 \\
\hline \multirow{2}{*}{ Number of kernels/spike } & 1 & 157.23 & 649.82 & 38.64 & 0.830 & 71.11 & 41.21 & 17.35 & 10.06 \\
\hline & 2 & 66.04 & 493.49 & 68.60 & 2.73 & 53.77 & 22.18 & 12.71 & 5.24 \\
\hline \multirow{2}{*}{ Wighet of 100 - grains } & 1 & 0.138 & 1.47 & 0.30 & 3.26 & 34.34 & 15.00 & 17.07 & 12.68 \\
\hline & 2 & 0.470 & 2.08 & 0.378 & 0.475 & 62.14 & 46.17 & 6.96 & 3.04 \\
\hline \multirow{2}{*}{ Grain yield/plant } & 1 & 47.43 & 3.84 & 19.11 & 0.284 & 67.54 & 54.11 & 34.34 & 27.67 \\
\hline & 2 & 60.24 & 143.16 & 18.99 & 1.54 & 62.68 & 60.63 & 24.75 & 23.94 \\
\hline
\end{tabular}

Predicted genetic advance as percent of $\mathrm{F}_{2}$ ranged from (2.36) for $\mathrm{PH}$ in hybrid 1 to $(27,67)$ for GYP in hybrid 1 and ranged from 5.08 for DH to 23.94 for GYP in cross 2. This led to a sufficient improvement in its variable characteristics and these results indicated the possibility of practicing selection in early generations and obtain high yielding genotypes. Moreover, the remaining traits, which found the low values expected genetic advance, suggesting the role of environmental factors and dominance gene action in inheritance system of these traits. These results are in accordance with the findings of Khattab et al. (2010), El- Aref et al. (2011), Amin (2013), Abd El- Rady (2018) and Elmassry et al. (2018), Hassan (1993) and Shafey et al. (1993) found that the highest genetic advance was obtained for plant height, weight of 1000 grains and GYP. On the other hand, Kuobisy (2011) reported that the genetic advance was generally low for all studied characters in the two hybrids, while, PH, and NKS in two crosses and GYP in cross 1 were 
moderate of genetic advance values. These results are of great interest for wheat breeders to improve yield potential and evacuation new wheat genotypes and enhancement of Egyptian wheat germplasm.

\section{References}

Abd El- Rady, A. G. (2018), "Genetic analysis of some agronomic traits in two bread wheat crosses under heat stress conditions", Journal of Plant production, Vol. 9 No. 1, pp. 21-28.

Abd El-Rahman, M. E. and Hammad, S. M. (2009), "Estimation of some genetic parameters for some agronomic characteristics in three crosses of bread wheat", Journal of Agricultural Science - Mansoura University, Vol. 34 No. 2, pp. 10911100.

Abd El-Rahman Magada, E. (2013), "Estimation of some genetic parameters through generations means analysis in three bread wheat crosses", Alexandria Journal of Agricultural Science, Vol. 58 No. 3, pp. 183-195.

Abd-Allah, Soheir M. H. and Mostafa, A. K. (2011), "Genetical analysis for yield and its attributes in bread wheat using the five parameters model", Journal of Plant Production, Vol. 2 No. 9, pp. 1171-1181.

Abd-Allah Soheir, M. H. and Hassan, M. A. (2012), "Quantitative traits inheritance in three bread wheat crosses", Alexandria Journal Agriculture Research, Vol. 57 No. 3, pp. 263-271.

Akhtar, N. and Chowdhry, M. S. (2006), "Genetic analysis and some other quantitative traits in bread wheat", International Journal of Agriculture and Biology, Vol. 8 No.4, pp. 523527.

Allard, R. W. (1960), Principles of Plant Breeding, Jhon Wiley and Sons, Inc., New York, USA, pp. 485.

Amin, I. A. (2013), "Genetic behavior of some agronomic traits in two durum wheat crosses under heat stress", Alexandria Journal of Agricultural Science, Vol. 58 No. 1, pp. 53-66.

Awaad, H. A. (1996), "Diallel analysis of yield and its contributing Characters in wheat (Triticum aestivum L.)", Zagazig Journal of Agricultural Research, Vol. 23, pp. 999-1012.

Braun, H. J., Atlin, G. and Payne, T. (2010), "Multilocation testing as a tool to identify plant response to global climate change", In: Reynolds, M. P. (Ed.), Climate change and crop production, $\mathrm{CABI}$, London, UK.

Burton, G. W. (1952), Quantitative inheritance in grasses, Proceedings of $6^{\text {th }}$ International Grassland Congress, Vol. 1, pp. 227-283.

Chandra, D., Islam, M. A. and Barma, N. C. D. (2004), "Variability and 
interrelationships of nine quantitative characters in $\mathrm{F}_{2}$ bulks of five wheat crosses", Pakistan Journal of Biological Sciences, Vol. 7 No. 6, pp. 1040-1045.

El-Aref, Kh. A. O., Tammam A. M., Ibrahim, M. M. and Koubisy, Y. S. I. (2011), "Generation mean analysis in bread wheat under drought conditions", Egyptian Journal of Applied Sciences, Vol. 26 No. 2, pp. 187-208.

El-Gammaal, A. A. and Yahya, A. I. (2018), "Genetic variability and heterosis in $F_{1}$ and $F_{2}$ generations of diallel crosses among seven Wheat genotypes", Journal of Plant Production, Vol. 9 No. 12, pp. 10751086.

Elmassry, E. L. and El-Nahas, M. M. (2018), "Genetic behavior of some agronomic characters in three Bread Wheat crosses under different environmental conditions", Alexandria Journal of Agricultural Science, Vol. 63 No.5, pp: 313-325.

El-Said Rania, A. R. (2018), "Assessment of genetical parameters of yield and its attributes in bread wheat (Triticum aestivum, L.)", Journal of Agricultural Chemistry and Biotechnology, Vol. 9 No. 10, pp. 243-251.

Falconer, D. S. (1989), Introduction to quantitative genetics, $3^{\text {rd }}$ ed., John Wiley \& Sons, Inc., 605 Third Avence, New York, NY 10158.
FAO (2012), Food and Agriculture Organization of United Nations, Vial delle terme di caraclla, Rome, Italy.

FAO (2019), FAOSTAT agriculture data, Agriculture production 2009, available at http:// faostat.fao.org, FAO, Rome, Italy.

Fethi, B. and Mohamed, E. G. (2010), "Epistasis and genotype by environment interaction of grain yield related traits in durum wheat", Journal of Plant Breeding and Crop Science, Vol. 2. No. 2, pp. 24-29.

Hassan, E. E. (1993), "Gene action for yield and its attributes and their implications in bread wheat breeding", Zagazig Journal of Agricultural Research, Vol. 20 No. 3 , pp. 949-955.

Hayman, B. I. (1958), "The separation of epistatic from additive and dominance variation in generation means", Heredity, Vol. 12 No. 3, pp. 371-390.

Jinks, J. L. and Jones, R. M. (1958), "Estimation of the components of heterosis", Genetics, Vol. 43 No. 2, pp. 23-234.

Khaled, M. A. I. (2013), "Genetic system controlling the yield and its components in three bread wheat (Triticum aestivum L.) crosses", Egyptian Journal of Agricultural Research, Vol. 91 No. 2, pp. 641653.

Khattab, A. B. (2009), "Genetic behavior 
of some traits of bread wheat (Triticum aestivum L.)", Journal of Sustainable Agricultural Sciences, Vol. 35 No. 2, pp. 446-479.

Khattab, S. A. M., Esmail, R. M. and Abd Al-Ansary, E. M. F. (2010), "Genetical analysis of some quantitative traits in bread wheat (Triticum aestivum L)", New York Science Journal, Vol. 3 No. 11, pp.152-157.

Kumar, A., Razdan, A., Sharma, V., Kumar, N. and Kumar, D. (2018), "Study of heterosis and inbreeding depression for economic and biochemical traits in bread Wheat (Triticum aestivum L.)", Journal of Pharmacognosy and Photochemistry, Vol.7 No. 4, pp. 558-564.

Kuobisy, Y. S. I. (2011), Generation mean analysis in bread wheat under drought conditions, M.Sc. Thesis, Faculty of Agriculture, Al-Azhar University, Assuit, Egypt.

Lal, C., Rattan S. M. and Kumar, V. (2013), "Generation mean analysis for some heat tolerance and quantitative in bread heat (Triticum aestivum L.)", Journal of Wheat Research, Vol. 5 No. 2, pp. 22-26.

Mather, K. and L-Jinks, J. (1982), Biometrics genetics, $3^{\text {rd }}$ edition, Chapman and Hall Ltd., London, England, pp. 396.
Mather, K. (1949), Biometrical genetics, Dover Publications, Inc., London, England.

Moussa, A. M. (2010), "Estimation of epistasis, additive and dominance variation in certain bread wheat (Triticum aestivum L.) crosses", Journal of Plant Production, Vol. 1 No. 12, pp. 1707-1719.

Shafey, A. S., Yassien, H. E. and Abd- ElMoneim, A. M. (1993), "Genetic analysis of some plant characters, yield and its components in three wheat crosses", Annals of Agricultural Science, Moshtohor, Vol. 31. No. 4, pp. 1889-1904.

Tammam, A. M. (2005), "Generation mean analysis in bread wheat under different environmental conditions", Minufiya Journal of Agricultural Research, Vol. 30. No. 3, pp. 937956.

Zaazaa, E. I., Hagerand, M. A. and ElHashash, E. F. (2012), "Genetical analysis of some quantitative traits in wheat using six parameters genetic model", American-Eurasian Journal of Agricultural \& Environmental Sciences, Vol. 12. No. 4, pp. 456462. 